\section{Når barn blir pårørende}

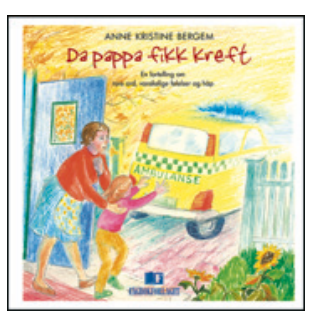

Anne Kristine Bergem

Da pappa fikk kreft

En fortelling om rare ord, vanskelige følelser og håp. 63 s, ill. Bergen: Fagbokforlaget, 2014 Pris NOK 275

ISBN 978-82-450-1638-3

Boken er en fagbarnebok, utgitt i samarbeid med BarnsBeste (Nasjonalt kompetansesenter for barn som pårørende) og Kreftforeningen. Forfatteren er lege og psykiater, og har lang erfaring med barn som pårørende.

Målgruppen er voksne og barn som sammen må forholde seg til alvorlig sykdom i nær familie, og boken er tenkt som en hjelp til å komme i gang med å sette ord på den vanskelige situasjonen.

Boken har to hoveddeler. I den første delen møter vi fortellingen om Astrid og hennes pappa som blir akutt og alvorlig syk på grunn av kreftsykdom. Videre beskrives de kaotiske og vanskelige følelsene som oppstår når pappa blir syk, hva som skjer i møte med sykehus og helsepersonell, alle de vanskelige ordene, usikkerheten og hverdagene som plutselig blir så annerledes. Flere steder i boken har forfatteren laget såkalte snakkebobler, som gir eksempler på gode spørsmål som kan stilles til barnet for å åpne opp for samtale om den aktuelle situasjonen barnet står i.

Den andre delen er en veileder for voksne som er nærpersoner til barn som opplever alvorlig sykdom i nær familie. Den forteller om barns behov for ærlig og sannferdig informasjon. Her får leseren konkrete råd og ideer til hvordan man kan inkludere barna og komme i gang med samtalen om det som skjer, og om de vanskelige følelsene. Det presenteres en enkel og lettfattelig forklaring på kreftsykdom og på ulike typer behandling, forløp og bivirkninger. I veilederdelen gis det eksempler på hvordan voksne kan bruke spørsmålene i snakkeboblene til utdypende samtaler med barnet.

Forfatteren henvender seg først og fremst til foreldre, men boken kan også brukes av andre familiemedlemmer, voksne i skoler og barnehager samt helsearbeidere i sykehus og i kommunehelsetjenesten. Den kan leses av barna alene, men er best egnet til å bli lest av barn og voksne sammen. Selv jobber jeg som kreftkoordinator $i$ en kommune, og kommer der i kontakt med barn og unge som er pårørende til nær familie med alvorlig sykdom. Jeg får ofte spørsmål fra foreldre om hjelp til kommunikasjonen med barna, om hvordan de skal involvere barna i det som skjer.

Jeg har allerede anbefalt boken til flere foreldrepar. Jeg anbefaler den gjerne til mine kolleger i helsevesenet og til ansatte i barnehager og skole. Jeg tror at alle som er i nær kontakt med barn og unge som pårørende, vil oppleve at dette er et verktøy som gir god hjelp i kommunikasjonen med barna.

Liv Reitan Gilberg

Kreftkoordinator, Levanger kommune

\section{Nyttig bok om unge som sliter}

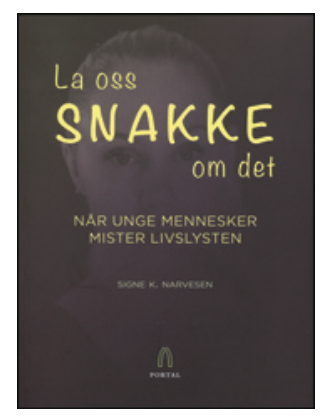

Signe K. Narvesen

La oss snakke om det

Når unge mennesker mister livslysten. $143 \mathrm{~s}$ ill. Kristiansand: Portal forlag, 2014. Pris 249 ISBN 978-82-8314-021-7

Boken er skrevet til unge mennesker som føler at livet er tungt, har selvmordstanker og ikke ser hvordan de kan komme seg ut av vanskene. Den er skrevet for å vise hvordan man på ulike måter kan komme seg videre selv om det føles håpløst i øyeblikket, ved å lese om andres historier og erfaringer, og ikke minst få tips til hva som kan være nyttig.

Forfatteren gir fem unge mennesker, fra 18 til 28 år, en stemme. De skriver hver sin historie om hvordan de har hatt det, og hvordan de har kommet seg ut av vanskene. Deretter vies det plass til tre personer som har erfaring fra frivillige krisetjenester, og til slutt til lederen ved Nasjonalt senter for selvmordsforskning og -forebygging (psykiater og professor dr.med. Lars Mehlum). Avslutningsvis er det en oversikt over ulike hjelpetelefoner/chattetjenester.

Flere har nevnt nettsteder og chattesteder som viktig hjelp. I og med at mange unge nettopp ikke deler sine tanker med andre rundt seg, kan slike nett-/chattesteder være avgjørende for at de tar kontakt.

Forfatterens valg av ressurspersoner synes noe snever. Som barneog ungdomspsykiater savner jeg fagpersoner innen barne- og ungdomspsykiatrien. Alle «jeg»-personene i boken er nå voksne, men historiene deres refererer til barne- og ungdomstiden. Dr. Mehlum er voksenpsykiater, men ledet nylig en studie der dialektisk atferdsterapi (DBT) beregnet for ungdom (DBT-A) viser lovende resultater med tanke på å redusere selvskade hos ungdom. I boken blir DBT spesielt omtalt som nyttig, og det står at en utvidelse av dette tilbudet kan redde liv. Dette er et sterkt utsagn som jeg lurer på om det finnes belegg for i forskning. BMJ Best Practice, oppdatert november 2014, skriver at ingen spesifikk psykoterapeutisk intervensjon har vist seg å redusere suicid. De fleste suicidintervensjonsterapier er undersøkt for effektivitet i forebygging av suicidalforsøk.

Familiefokusert behandling og mentaliseringsbasert terapi har også vist lovende resultater. Mer forskning på området er ønskelig før man kan konkludere med en bestemt effektiv terapiform.

Alt $i$ alt synes jeg boken er nyttig ved at den gir ansikt til unge som sliter, og den formidler en følelse av at det nytter å komme seg ut av håpløsheten. De unges historier og deres løsninger mener jeg er leseverdige. Informasjon med kontaktopplysninger til aktuelle lavterskel hjelpesteder er meget nyttig. Hvorvidt målgruppen vil ta seg tid til å lese en slik bok, er derimot mer usikkert. Boken kan være nyttig å lese for fagfolk, pårørende og venner til ungdom som sliter, men den gir en noe ensidig fremstilling av terapiformer som virker.

\section{Kristin Holseth}

Barne- og ungdomspsykiater, Klinikk for psykisk helse og avhengighet, Avdeling for nasjonale og regionale funksjoner

Oslo universitetssykehus 